\title{
Romances latino-americanos subversivos: leitura e escrita a contrapelo da heteronormatividade*
}

\section{Camila Marchesan Cargnelutti**}

Em seu primeiro livro, publicado pela Editora Mulheres em 2012, Anselmo Peres Alós investiga as possibilidades de apreensão de uma poética sexual em três romances latino-americanos da segunda metade do século $\mathrm{XX}$, de forma a buscar no campo ficcional aspectos e apostas características dos textos mobilizados que funcionem como uma forma de resistência e questionamento dos princípios e das práticas heteronormativas. Para tanto, as obras eleitas para a análise são El beso de la mujer araña (1976), do argentino Manuel Puig, Onde andará Dulce Veiga? (1990), do brasileiro Caio Fernando Abreu, e No se lo digas a nadie (1994), do peruano Jaime Bayly. Ao analisar pelo viés comparativo as obras acima, Alós procura uma poética queer, entendida como uma poética revestida de um caráter transautoral - por "preocupar-se com uma poética trespassada pela subjetividade de um grupo social específico" (p. 71).

Ao longo de sua obra, Alós problematiza as narrativas literárias $e$ as reflexões a respeito de relações de gênero, sexualidade, construção de identidades e nacionalidades na América Latina. Os pressupostos teóricos que guiam a análise do autor são contemplados no primeiro capítulo ("Epistemologia como política do conhecimento: pressupostos para a construção

* Recebida em 13 de maio de 2014, aceita em 27 de julho de 2017. Resenha do livro Alós, Anselmo Peres. A letra, o corpo e o desejo: masculinidades subversivas no romance latino-americano. Florianópolis, Editora Mulheres, 2012. ** Mestranda do Programa de Pós-Graduação em Letras da Universidade Federal de Santa Maria - Mestrado em Letras (PPGL/UFSM), Santa Maria, RS, Brasil.camila.m.cargnelutti@gmail.com 
de uma poética queer"), no qual se encontram discussões a respeito de corpo, gênero e sexo, baseadas em autoras como Judith Butler (2003) e Jane Flax (1992). Uma das questões fundamentais para o entendimento dos princípios que orientam a construção reflexiva e os argumentos desenvolvidos pelo autor diz respeito à performatividade. Destarte, os romances performativos assumem um papel fundamental como escritas de resistência e de subversão, pois, simultaneamente, nomeiam e criam aquilo que foi nomeado - "ficcionalizam uma realidade social ao mesmo tempo em que a constroem" (p. 43).

E se pensarmos a literatura e a ficção também como uma forma de representação e de constituição de sujeitos, observando previamente que existe um sujeito canônico e típico (homem, heterossexual, branco), a função subversiva e de resistência das narrativas analisadas na obra de Alós assumem nova e redobrada importância. Os romances de Manuel Puig, Caio Fernando Abreu e Jaime Bayly - e a poética queer que Alós busca nessas obras possibilitam a emergência de outros tipos de sujeitos, diferentes, desviantes - masculinidades subversivas em relação à representação masculina tradicional. El beso de la mujer araña, Onde andará Dulce Veiga? e No se lo digas a nadie representariam a ficcionalização e, ao mesmo tempo, a criação de uma realidade que envolve sexualidades subalternizadas, a expressão do desejo homossexual e a resistência aos padrões heteronormativos.

Nesse sentido, a leitura - e a escrita - política de Anselmo Peres Alós, ao debater masculinidades subversivas com foco no romance latino-americano contemporâneo lança nova luz sobre tão importantes e atuais questões no cenário de um espaço territorial que possui tantas particularidades em sua formação, tais como as memórias de repressões e violências ditatoriais que sangraram, na segunda metade do século $\mathrm{XX}$, diversos países latino-americanos, incluindo Argentina, Brasil e Peru, as três nações representadas no corpus do trabalho do autor.

Uma preocupação constante quando se trabalha com "América Latina" - e se procura sua autenticidade $e$ 
idiossincrasias em relação aos estudos desenvolvidos na América do Norte ou na Europa, particularmente - diz respeito justamente à consideração das diferenças em sua formação. Essa premissa básica, no entanto, deve ser considerada também entre os próprios países que compõem o imenso território latinoamericano. Ao realizar investigações desse teor, não se pode cair nas disposições do senso comum e tratar a América localizada ao sul (ou ao norte, dependendo do ponto de vista adotado) dos Estados Unidos como una e homogênea, uma vez que, apesar de um histórico muitas vezes semelhante de opressões, violências, colonizações e ditaduras, do México à Argentina, do Brasil ao Equador, são muitas as particularidades de cada país e as variadas maneiras de expressão artística, literária e cultural dessas diferenças.

Mesmo ao afirmar uma certa homogeneidade na América Latina no que se refere à construção de um típico sujeito ou de uma identidade nacional que privilegie sujeitos masculinos heterossexuais, com características comuns observadas nos romances dos países latino-americanos abrangidos pela pesquisa, o autor soube tratar essa temática e modalizar suas generalizações. Tal preocupação pode ser percebida, por exemplo, na contextualização da conjuntura sócio-histórica dos países em questão, da consideração da diversidade em que as obras foram criadas, da demarcação de certas peculiaridades em relação aos autores e às publicações e da não imposição de um jeito único de ver continente tão vasto.

Do segundo capítulo do livro ("O corpo da tese, ou: o corpus fora do armário"), que traz especificações dos procedimentos de leitura mobilizados para a análise interpretativa desenvolvida, é importante destacar as considerações sobre intencionalidade do autor em uma obra. Sobre essa questão, Alós afirma que, "mais do que a intencionalidade do autor, é a performance semiótica realizada pelo texto literário a principal responsável pela articulação e produção dos sentidos" (p. 88). Assim, os textos literários devem ser considerados também como artefatos culturais com valor simbólico, relacionados ao contexto 
histórico-social de sua produção, e que articulam, além de suas especificidades literárias e formais, questões políticas que partem de um lugar de enunciação ideologicamente constituído.

A partir do momento que esses sujeitos de enunciação, carregados de ideologias, constroem seus discursos, particularmente na forma de romances como nos casos considerados na pesquisa de Alós, a literatura se configura como um espaço para a textualização de experiências, desejos e afetos homossexuais. Assim, esses textos literários possibilitam dar voz a outras formas de vivência da sexualidade, outras representações de identidades no campo da literatura, referentes a sujeitos historicamente silenciados. Dessa forma, a escrita literária poderia contribuir para a relativização de valores heteronormativos e para a desestabilização de estereótipos de identidade nacional calcados no masculino e na heterossexualidade, na medida em que desvelaria a existência $e$ as experiências de uma multiplicidade de sujeitos, não contemplada pela lógica heteronormativa.

Essa é uma das principais reflexões propostas por Alós em seu capítulo final, após a exposição minuciosa de sua interpretação crítica referente aos romances de Puig, Abreu e Bayly, desenvolvida no capítulo 3 ("Binarismos de gênero e heteronormatividade: focalização e subversão"), com foco na questão da voz narrativa e nos procedimentos de focalização, e no capítulo 4 ("A articulação de novos arranjos de sociabilidade sexual: a revolução sexual nas margens do texto"), com destaque para os questionamentos a respeito das identidades nacionais $e$ sexuais constituídas a partir da emergência de vozes até então silenciadas.

O autor relembra, no último capítulo de seu livro - "Das ficções (políticas) à política (das ficções)" -, uma citação de Fredric Jameson (1992) sobre o ato de interpretar uma narrativa constituirse como um ato socialmente simbólico. Também o ato de narrar construído pelos escritores Manuel Puig, Caio Fernando Abreu e Jaime Bayly são atos socialmente simbólicos, "com a capacidade de dialogar, desestruturar e subverter os saberes institucionalizados pelos discursos da biologia, da religião e da psicologia, bem como 
os saberes hegemônicos que circulam sob o rótulo do senso comum" (p. 204). Nesse sentido, também o exercício narrativo se configura como um ato performativo, capaz de interferir na realidade social a partir da configuração de diferentes identidades sexuais e de gênero, questionando a matriz heterossexual $e$ possibilitando novas formas de reconhecimento para os sujeitos sociais "subversivos" por meio do texto literário.

Se, conforme o autor faz questão de esclarecer logo na introdução de seu livro, "toda leitura é política" (p. 16) ao falar sobre possíveis implicações de subjetividades em suas interpretações das obras, pode-se reiterar que também sua escrita configura-se como um espaço de exercício político de resistência e de contestação de princípios sexistas e heteronormativos que ainda hoje insistem em pregar a superioridade masculina e em padronizar como binária (tanto em relação ao corpo e ao gênero quanto à sexualidade) uma sociedade intrinsecamente heterogênea, constituída de desvios e de entre-lugares, que, definitivamente, não podem ser abarcados dentro de uma perspectiva que tem como princípio básico o dualismo masculino $e$ feminino.

\section{Referências bibliográficas}

BUtLER, Judith. Problemas de gênero: feminismo e a subversão da identidade. Rio de Janeiro, Civilização Brasileira, 2003. [Tradução: Renato Aguiar].

FLAX, Jane. Pós-modernismo e relações de gênero na teoria feminista. In: Hollanda, Heloísa Buarque de (org.). Pós-modernismo e política. Rio de Janeiro, Rocco, 1992, pp. 217-250.

JAMESON, Fredric. A interpretação: a literatura como ato socialmente simbólico. In: O inconsciente político. São Paulo, Ática, 1992, pp.15-103. [Tradução: Valter Lellis Siqueira]. 